Bull. Chem. Soc. Ethiop. 2003, 17(1), 1-9.

Printed in Ethiopia

ISSN 1011-3924

(c) 2003 Chemical Society of Ethiopia

\title{
COMPARISON OF SOME PRECONCENTRATION METHODS FOR CERTAIN METAL IONS IN HUMAN MILK AND YOGURTS
}

\author{
F.O. Nwosu ${ }^{*}$, F.A. Adekola and E. Ibitoye \\ Department of Chemistry, University of Ilorin, P.M.B. 1515, Ilorin, Nigeria
}

(Received April 4, 2002; revised March 19, 2003)

\begin{abstract}
Five samples each of yogurts and human milk were separately collected, deproteinized, pre-concentrated differently with $1 \%$ 8-hydroxyquinoline, $1 \%$ ammonium pyrrolidine-dithiocarbamate (APDC) and extracted with methyl-isobutylketone (MIBK). Activated carbon powder in $\mathrm{HNO}_{3}$ was also used. The extracts obtained were analyzed using atomic absorption spectrometry for some metal ions. In yogurts, the powdered activated carbon in $\mathrm{HNO}_{3}$ exhibited the highest complexing ability with values of $0.04-0.17,335-476,1.52-3.82,0.08-0.27$, $0.09-0.28,1.31-8.78$ and 888-12693 mg/L concentration for $\mathrm{Zn}^{2+}, \mathrm{Mg}^{2+}, \mathrm{Mn}^{2+}, \mathrm{Cr}^{3+}, \mathrm{Cu}^{2+}, \mathrm{Fe}^{3+}$ and $\mathrm{Ca}^{2+}$, respectively. The concentrations of $\mathrm{Zn}^{2+}, \mathrm{Mg}^{2+}, \mathrm{Mn}^{2+}, \mathrm{Cr}^{3+}, \mathrm{Cu}^{2+}, \mathrm{Fe}^{3+}$ and $\mathrm{Ca}^{2+}$ ions were determined to be in the range of 0.02-0.03, 1.10-9.47, 0.05-0.11, 0.02-3.08, 0.01-0.87, 0.47-18.08, $<0.01-278 \mathrm{mg} / \mathrm{L}$, respectively, for APDC/MIBK extraction method. The complexing ability of APDC/MIBK appeared to be the lowest. The $\mathrm{Co}^{3+}$ and $\mathrm{Cd}^{2+}$ ions were only detected by activated carbon pre-concentration method. A more or less similar trend was obtained for human milk samples. For all samples, the complexing ability of each of the complexing agents varied from one metal ion to another.
\end{abstract}

KEY WORDS: Human milk, Yogurts, Pre-concentration methods, Metal ions determination, 8Hydroxyquinoline, Ammonium pyrrolidine-dithiocarbamate, Activated carbon powder

\section{INTRODUCTION}

All organisms require certain essential inorganic metal ions in their body system for life processes while some metal ions are dangerous and detrimental to life. Some metal ions occur in the body system at low concentration such that only recent analytical methods could ascertain their quantity. These metal ions include $\mathrm{Ca}, \mathrm{Co}, \mathrm{Cu}, \mathrm{Cr}, \mathrm{Fe}, \mathrm{Mn}, \mathrm{Mg}, \mathrm{Zn}, \mathrm{K}$, and $\mathrm{Na}$. An excellent review on the roles of these metals in the body has been carried out [1-4].

It is generally believed that lactating mothers should exclusively breast-feed their babies for at least six months so that they can be healthy, grow well and develop good immune system. The proper growth and good health of babies may depend on the quality of food the mothers fed on during pregnancy and lactating periods. Thus, the nutrient content of breast milk that will be produced by these lactating mothers may vary accordingly. Trace elements values for $\mathrm{Al}$, As, $\mathrm{Cd}, \mathrm{Co}, \mathrm{Sr}, \mathrm{Cu}, \mathrm{F}, \mathrm{Mn}, \mathrm{Ni}, \mathrm{Pb}, \mathrm{Rb}, \mathrm{Sc}, \mathrm{Se}, \mathrm{V}$ and $\mathrm{Zn}$ in blood, serum and urine in two European countries; Czech and Slovak have also been assessed to indicate health status of general population as well as occupational groups exposed to trace elements [5]. The variation in concentration levels of $\mathrm{Cu}, \mathrm{Zn}$, and $\mathrm{Mg}$ versus period of milk production was studied. It was found that $\mathrm{Cu}$ levels fell from $0.46 \mathrm{mg} / \mathrm{mL}$ in colostrum to $0.17 \mathrm{mg} / \mathrm{mL}$ between 7 to 12 months of lactation, Zn levels fell from $5.32 \mathrm{mg} / \mathrm{mL}$ to $1.12 \mathrm{mg} / \mathrm{mL}$ by 7 months and $\mathrm{Mg}$ level in colostrum was $40 \mathrm{mg} / \mathrm{mL}$ and reduced to $30 \mathrm{mg} / \mathrm{mL}$ in matured milk samples [6].

It has been reported that during lactation, there is an increased maternal loss of $\mathrm{Zn}$ that secretes into the human milk [7]. The first six months of lactation has been found to contain approximate $0.11 \mathrm{mg} / \mathrm{mL}$ of $\mathrm{Zn}$, which decreases to $0.06 \mathrm{mg} / \mathrm{mL}$ in the next six months. A study

*Corresponding author. E-mail: nwooyef@unilorin.edu.ng 
on the levels of $\mathrm{Cu}, \mathrm{Zn}, \mathrm{Fe}, \mathrm{Mn}, \mathrm{Ca}, \mathrm{Al}, \mathrm{Mg}, \mathrm{P}, \mathrm{Ba}, \mathrm{Se}$, and $\mathrm{Sr}$ in human milk of some lactating mothers and hair specimen of healthy infants have been carried out [8]. The statistical analysis showed that the level of $\mathrm{Zn}$ in infant hair with human milk feeding was significantly higher than those without breast milk feeding at $99 \%$ probability level. A recent study has also shown that the health status of lactating mothers appeared to have no significant effect on the level of protein and trace elements in human milk [9].

Despite the claim for solely human milk feeding of infants, it has been reported that complementary foods for infant feeding (9-11 months) in developing countries be encouraged [10]. The complementary foods should provide supplements for trace elements such as $\mathrm{Cu}, \mathrm{Ca}$, $\mathrm{Mn}, \mathrm{Zn}, \mathrm{P}$ and Fe. More so, whenever the lactating mother is seriously ill, it might be necessary to supplement the breast-feeding of the child [11].

Yogurts are slightly soured thick liquid food consisting of milk and are taken by many people, particularly by the children in the third world countries like Nigeria. The major problem involved in the determination of the nutritional status of both the human milk and yogurts in respect to trace metals is making the right choice of sample pretreatment before analysis. Direct determination with atomic absorption spectrometry often lead to low level of precision as a result of presence of these metals at very low concentration. Many workers have therefore concentrated their efforts on studies on pretreatment methods so as to raise the detection levels. Prior to pre-concentration process, deproteination of milk is necessary. Trichloroacetic and salicylic acids have been reported to be effective as deproteination agents [12]. The use of ammonium pyrrolidinedithiocarbamate-methylisobutyl ketone extraction system has been reported for the determination of $\mathrm{Ag}, \mathrm{Cd}, \mathrm{Co}, \mathrm{Cr}, \mathrm{Cu}, \mathrm{Fe}, \mathrm{Ni}, \mathrm{Mn}$. and $\mathrm{Pb}$ in portable water [13]. The influence of $\mathrm{pH}$, extraction time and reagent stability on the use of ammonium-pyrrolidine dithiocarbamate (APDC) and ammoniumdiethyl dithiocarbamate for the determination of $\mathrm{Cd}$, $\mathrm{Co}, \mathrm{Cu}, \mathrm{Fe}, \mathrm{Pb}, \mathrm{Ni}, \mathrm{Ag}$ and $\mathrm{Zn}$ in aqueous solutions has also been examined [14]. The efficiency of ammonium pyrrolidine dithiocarbamate-isobutyl methylketone has again been compared with the column chelation procedure using immobilized 8-hydroxylquinoline on a controlled glass pore support for $\mathrm{Pb}$ and $\mathrm{Cu}$ in both sea and river water [15]. Furthermore, direct determination of $\mathrm{Ca}$ and $\mathrm{Mg}$ concentration in human milk using atomic absorption spectrometry after digestion with nitric acid and 8-hydroxyquinoline-methylisobutylketone has also been investigated [16].

The objective of this work is therefore to investigate the analytical performance of 8 hydroxylquinoline/MIBK, APDC/MIBK, and powdered activated charcoal/ $\mathrm{HNO}_{3}$ as preconcentration agents for trace metals in milk samples.

\section{EXPERIMENTAL}

\section{Sample collection}

Five different samples of yogurts produced by five manufacturers were purchased from Ilorin, Nigeria while five samples of human milk were collected from lactating mothers at children specialist hospital, Ilorin, Kwara State, Nigeria. The human milk samples were extremely difficult to collect due to African superstitious believes.

\section{Reagents}

All chemicals used were of analytical grade unless otherwise specified. The reagents used included: methylisobuthylketone (MIBK) (Graffin \& George) - minimum assay (99\%), 8hydroxyquinoline $(\mathrm{BDH})-1 \% \mathrm{w} / \mathrm{v}$ in distilled water, ammonium pyrrolidinedithiocarbamate $(\mathrm{BDH})-$ minimum assay $(98 \%)-1 \% \mathrm{w} / \mathrm{v}$ in distilled water, $1.1 \mathrm{M} \mathrm{HNO}_{3}, 2 \mathrm{M} \mathrm{NaOH}$, solid salicylic acid, activated charcoal $(\mathrm{BDH})$. 


\section{Procedure}

About $2.0 \mathrm{~g}$ of salicylic acid and $80 \mathrm{~mL}$ of distilled water were added to $20.0 \mathrm{~g}$ of each of the five yogurt samples. The mixture was vigorously shaken, inverted every 5 minutes for about 45 minutes and was filtered with Whatman No. 1 filter paper to obtain a clear filtrate. This was made up to $100 \mathrm{~mL}$ mark of the standard volumetric flask by washing residue obtained with $2 \%$ w/v salicylic acid. This process removed protein from the mixture and has been fully described elsewhere [12]. The $\mathrm{pH}$ of the clear filtrate was adjusted to 5 with $2 \mathrm{M} \mathrm{NaOH}$ using Kent EIL $7055 \mathrm{pH}$ meter. The same process was repeated for the human milk except that about $0.8 \mathrm{~g}$ of salicylic acid, $40 \mathrm{~mL}$ of distilled water and $8.0 \mathrm{~g}$ of human milk were used. The metal ions in yogurt filtrate was firstly preconcentrated with 8-hydroxylquinoline in MIBK [16] by addition of $5 \mathrm{~mL}$ of $1 \%$ 8-hydroxylquinoline solution to $90 \mathrm{~mL}$ of the filtrate in a separating flask and extracted with $20 \mathrm{~mL}$ methyl isobutylketone (MIBK). The organic upper layer was de-extracted using $10 \mathrm{~mL}$ of $6 \mathrm{M} \mathrm{HCl}$ in a separating flask to obtain a lower aqueous layer for each of the yogurt samples labeled A1, B1, C1, I1, and $\mathrm{J} 1$. The pre-concentration procedure was repeated using $5 \mathrm{~mL}$ of $1 \%$ ammonium pyrolidine-dithiocarbamate (APDC) for yogurt filtrates to obtain samples labeled A2, B2, C2, I2, and J2. The ability of activated carbon/ $\mathrm{HNO}_{3}$ acid to preconcentrate trace metals in yogurt filtrates was also investigated by addition of $10.0 \mathrm{~g}$ of commercial activated carbon powder into $90 \mathrm{~mL}$ filtrate. The whole lot was placed on an electrothermal heater at about $120^{\circ} \mathrm{C}$ and allowed to gently evaporate with occasional swirling in a fume cupboard. The evaporation should just be to the extent that the activated carbon is wet and not completely dry. It was allowed to cool and $40 \mathrm{~mL}$ of $1.1 \mathrm{M} \mathrm{HNO}_{3}$ was added, swirled and filtered to obtain A3, B3, C3, I3, and J3. Similarly the metal ions in each of the deproteinized human milk filtrates were pre-concentrated by addition of $5 \mathrm{~mL}$ of $1 \% 8$ hydroxylquinoline solution to $20 \mathrm{~mL}$ of the milk filtrate in a separating flask, and extracted with $20 \mathrm{~mL}$ MIBK. Other steps were the same as in yogurt samples for human milk filtrate to obtain samples D1, E1, F1, G1, and H1. Samples D2, E2, F2, were obtained for human milk using APDC/MIBK pre-concentration method. The activated carbon $/ \mathrm{HNO}_{3}$ acid extraction system involved addition of about $4.0 \mathrm{~g}$ of activated carbon powder to $20 \mathrm{~mL}$ of the milk filtrate, placed on an electrothermal heater at about $120^{\circ} \mathrm{C}$ in a fume cupboard; and swirled occasionally. It was cooled and $40 \mathrm{~mL}$ of $1.1 \mathrm{M} \mathrm{HNO}_{3}$ acid was added, swirled and filtered to obtain $\mathrm{G} 3$ and $\mathrm{H} 3$ preconcentrated human milk samples. The concentrations of all the filtrate samples for both yogurts and human milk were measured with an Alpha ChemTech Analytical, U.K. atomic absorption spectrophotometer coupled with IBM 425SX computer and Alpha 4 soft ware. An air-acetylene flame atomization method was used. The instrument was operated as per the instrument's manual. The blanks were used for zeroing the instrument before each analysis to avoid matrix interference. The blanks were prepared by subjecting the doubly distilled water to the same treatment of pre-concentration as the human milk and the yogurt samples. The original filtrate samples obtained from deproteination process prior to the application of pre-concentration agents were also analyzed using AAS. These were labeled As, Bs, Cs, Is and Js for yogurt samples. The control samples were obtained by following the process of deproteination and preconcentration with each of the pre-concentrating agent but without the use of human milk or yogurt samples. The sample used was re-distilled water.

\section{RESULTS AND DISCUSSION}

The results of this study are presented in Tables 1-7. Table 1 is the results showing the regular food types taken by the lactating mothers and the period of breast-feeding their babies. One of the lactating mothers complemented breast-feeding her baby with custard and powdered milk. 
Table 2 shows the concentration of metal ions in the control samples. Tables 3 and 4 show various metal ion concentrations present in the yogurts and human milk, respectively. In yogurts, the concentration of $\mathrm{Zn}^{2+}, \mathrm{Mg}^{2+}, \mathrm{Mn}^{2+}, \mathrm{Cr}^{3+}, \mathrm{Cu}^{2+}, \mathrm{Fe}^{3+}$ and $\mathrm{Ca}^{2+}$ ions were found to be in the ranges of $0.15-0.22,0.60-50.65,0.04-0.21,0.02-0.11,0.06-0.12,0.62-2.68,2.95-94.65$ $\mathrm{mg} / \mathrm{L}$, respectively, with the use of 8-hydroxylquinoline as complexing agent. The concentrations of $\mathrm{Zn}^{2+}, \mathrm{Mg}^{2+}, \mathrm{Mn}^{2+}, \mathrm{Cr}^{3+}, \mathrm{Cu}^{2+}, \mathrm{Fe}^{3+}$, and $\mathrm{Ca}^{2+}$ metal ions were determined to be in the ranges of $0.02-0.03,1.10-9.47,0.05-0.11,0.02-3.08,0.01-0.87,0.47-18.08,<0.01-$ $278.20 \mathrm{mg} / \mathrm{L}$, respectively, for the APDC/MIBK pre-concentration method while those of powdered activated carbon/ $\mathrm{HNO}_{3}$ pre-concentration method has values of $0.04-0.17,335-476$, $1.52-3.82,0.08-0.27,0.09-0.28,1.31-8.78$ and $888-12693 \mathrm{mg} / \mathrm{L}$ for $\mathrm{Zn}^{2+}, \mathrm{Mg}^{2+}, \mathrm{Mn}^{2+}, \mathrm{Cr}^{3+}$, $\mathrm{Cu}^{2+}, \mathrm{Fe}^{3+}$ and $\mathrm{Ca}^{2+}$ ions, respectively. In the yogurt samples, concentrations of $\mathrm{Co}^{3+}$ and $\mathrm{Cd}^{2+}$ ions were very low, generally less than $0.01 \mathrm{mg} / \mathrm{L}$. However in some samples using powdered activated carbon, concentrations of $\mathrm{Co}^{3+}$ and $\mathrm{Cd}^{2+}$ ions fell in the ranges of $0.29-0.88$ and $0.08-$ $0.12 \mathrm{mg} / \mathrm{L}$, respectively. The $\mathrm{Cd}^{2+}$ ion was detected only in two samples of the yogurt. The preconcentration methods appeared to be selective with respect to different metal ions. In terms of pre-concentration action, various methods examined could be ranked thus:

for $\mathrm{Zn}^{2+}$ ion: 8-hydroxylquinoline-MIBK > activated carbon- $\mathrm{HNO}_{3}>$ APDC-MIBK;

for $\mathrm{Mg}^{2+}$ and $\mathrm{Ca}^{2+}$ ions: activated carbon- $\mathrm{HNO}_{3}>$ APDC-MIBK $\geq 8$-hydroxylquinolineMIBK;

for $\mathrm{Mn}^{2+}$ ions: activated carbon- $\mathrm{HNO}_{3}>8$-hydroxylquinoline-MIBK > APDC-MIBK;

for $\mathrm{Cr}^{3+}$ ion: activated carbon- $\mathrm{HNO}_{3}>8$-hydroxylquinoline-MIBK $>$ APDC-MIBK

(an exception is found in sample A2 with APDC-MIBK exhibiting the relatively highest concentration of $3.08 \mathrm{mg} / \mathrm{L}$ );

for $\mathrm{Cu}^{2+}$ ions: activated carbon- $\mathrm{HNO}_{3}>8$-hydroxylquinoline-MIBK $>$ APDC-MIBK

(an exception is also found in sample A2 with APDC-MIBK exhibiting the highest concentration of $0.87 \mathrm{mg} / \mathrm{L}$ );

for $\mathrm{Fe}^{3+}$ ions: activated carbon- $\mathrm{HNO}_{3}>$ 8-hydroxylquinoline-MIBK > APDC-MIBK;

for $\mathrm{Co}^{2+}$ and $\mathrm{Cd}^{2+}$ : activated carbon- $\mathrm{HNO}_{3}>8$-hydroxylquinoline-MIBK $=$ APDC-MIBK.

Table 1. Period of breast-feeding babies and major food types of mothers.

\begin{tabular}{|c|c|c|c|c|}
\hline $\begin{array}{c}\text { Human } \\
\text { milk } \\
\text { samples }\end{array}$ & $\begin{array}{c}\text { Regular food } \\
\text { types of mothers }\end{array}$ & $\begin{array}{c}\text { Solely on } \\
\text { human milk: } \\
\text { (Yes or No) }\end{array}$ & $\begin{array}{c}\text { Types of complimentary } \\
\text { baby food }\end{array}$ & $\begin{array}{c}\text { Period of breast- } \\
\text { feeding } \\
\text { (month) }\end{array}$ \\
\hline D & Pounded yam & Yes & -- & 1.3 \\
\hline E & Yam flour & Yes & -- & 3.0 \\
\hline F & Yam flour & Yes & -- & 1.0 \\
\hline G & Rice and beans & No & Custard and powdered milk & 2.5 \\
\hline H & Rice and beans & Yes & -- & 2.0 \\
\hline
\end{tabular}

Table 2. Concentration of metal ions in control samples.

\begin{tabular}{|l|l|l|l|l|l|l|l|l|l|l|}
\hline & $\begin{array}{l}\text { Control } \\
\text { sample }\end{array}$ & $\mathrm{Zn}$ & $\mathrm{Mg}$ & $\mathrm{Co}$ & $\mathrm{Cd}$ & $\mathrm{Mn}$ & $\mathrm{Cr}$ & $\mathrm{Cu}$ & $\mathrm{Fe}$ & $\mathrm{Ca}$ \\
\hline 8-Hydroxyquinoleine/MIBK & $\mathrm{S}$ & 0.05 & 0.25 & 0.03 & 0.03 & 0.02 & 0.01 & 0.01 & 0.04 & 1.15 \\
\hline $\begin{array}{l}\text { Ammonium } \\
\text { pyrolidinedithio-cabarmate }\end{array}$ & $\mathrm{S}$ & 0.01 & 0.32 & 0.00 & 0.03 & 0.01 & 0.04 & 0.02 & 0.02 & 0.05 \\
\hline $\begin{array}{l}\text { Powdered activated } \\
\text { carbon/HNO }\end{array}$ & $\mathrm{S}$ acid & 0.09 & 0.54 & 0.00 & 0.2 & 0.28 & 0.16 & 0.02 & 0.48 & 17.3 \\
\hline
\end{tabular}

Sample $\mathrm{S}$ is redistilled water, concentration in $\mathrm{mg} / \mathrm{L}$. 
In yogurts (Table 3), the concentrations of metal ions determined directly without the use of complexing agents were found lower than those complexed with 8-hydroxylquinoline with exception of $\mathrm{Mg}^{2+}$ and $\mathrm{Ca}^{2+}$ ions. It was also observed that the concentrations of metal ions determined directly without the use of APDC, are higher than the complexed ones for $\mathrm{Mn}^{2+}$, $\mathrm{Cr}^{2+}, \mathrm{Cu}^{2+}, \mathrm{Fe}^{2+}$. For the powdered activated carbon, the concentrations of all complexed metal ions are higher than those determined directly without the use of powdered activated carbon. The activated carbon effectively complexed $\mathrm{Mg}^{2+}$ and $\mathrm{Ca}^{2+}$ ions while it poorly complexed $\mathrm{Zn}^{2+}$ ions. The 8-hydroxylquinoline complexing agent effectively complexed $\mathrm{Zn}^{2+}$ ions while APDC poorly complexed it in line with general view in literature [16]. Activated carbon exhibited the highest complexing ability towards all metal ions considered while APDC exhibited the least complexing capacity. Furthermore, the concentrations of $\mathrm{Co}^{3+}, \mathrm{Cd}^{2+}$ and $\mathrm{Mn}^{2+}$ ions were below $0.01 \mathrm{mg} / \mathrm{L}$ with the use of powdered activated carbon; concentration values for these metal ions were obtained. It is also obvious that $\mathrm{Cr}^{3+}$ and $\mathrm{Cu}^{2+}$ ions were below $0.01 \mathrm{mg} / \mathrm{L}$ in certain yogurt samples determined without the use of complexing agent but higher concentration values were obtained when complexing agents were used. Thus, APDC and 8-hydroxyquinoline may not be appropriate for a more or less accurate metal ion determination in yogurt samples.

Table 3. Concentration of metal ions in yogurts.

\begin{tabular}{|c|c|c|c|c|c|c|c|c|c|c|}
\hline & & $\mathrm{Zn}$ & $\mathrm{Mg}$ & Co & $\mathrm{Cd}$ & $\mathrm{Mn}$ & $\mathrm{Cr}$ & $\mathrm{Cu}$ & $\mathrm{Fe}$ & $\mathrm{Ca}$ \\
\hline \multirow{5}{*}{$\begin{array}{l}\text { 8-Hydroxyquinoleine } \\
\text { MIBK }\end{array}$} & A1 & 0.16 & 0.60 & $<0.01$ & $<0.01$ & 0.04 & 0.02 & 0.06 & 0.62 & 2.95 \\
\hline & $\mathrm{B} 1$ & 0.22 & 1.74 & $<0.01$ & $<0.01$ & 0.21 & 0.05 & 0.12 & 1.69 & 18.5 \\
\hline & C1 & 0.17 & 0.60 & $<0.01$ & $<0.01$ & $<0.01$ & 0.06 & 0.07 & 2.68 & 3.65 \\
\hline & I1 & 0.17 & 2.11 & $<0.01$ & $<0.01$ & $<0.01$ & 0.11 & 0.09 & 0.90 & 94.65 \\
\hline & $\mathrm{J} 1$ & 0.15 & 50.65 & $<0.01$ & $<0.01$ & 0.21 & 0.11 & 0.11 & 0.91 & 13.35 \\
\hline \multirow{5}{*}{$\begin{array}{l}\text { Ammonium } \\
\text { pyrolidinedithio- } \\
\text { cabarmate }\end{array}$} & A2 & 0.03 & 1.10 & $<0.01$ & $<0.01$ & $<0.01$ & 3.08 & 0.87 & 18.08 & 41.4 \\
\hline & B2 & 0.02 & 1.38 & $<0.01$ & $<0.01$ & $<0.01$ & 0.03 & 0.04 & 0.49 & 2.0 \\
\hline & C2 & 0.02 & 1.10 & $<0.01$ & $<0.01$ & $<0.01$ & 0.03 & 0.03 & 2.13 & $<0.01$ \\
\hline & $\mathrm{I} 2$ & 0.02 & 9.47 & $<0.01$ & $<0.01$ & 0.05 & 0.12 & 0.08 & 11.05 & 278.2 \\
\hline & $\mathrm{J} 2$ & 0.02 & 1.19 & $<0.01$ & $<0.01$ & 0.11 & 0.02 & 0.01 & 0.47 & 15.3 \\
\hline \multirow{5}{*}{$\begin{array}{l}\text { Powdered activated } \\
\text { carbon/ } / \mathrm{HOO}_{3} \text { acid }\end{array}$} & A3 & 0.08 & 475.5 & $<0.01$ & $<0.01$ & 3.82 & 0.18 & 0.20 & 7.01 & 5320 \\
\hline & B3 & 0.04 & 334.5 & 0.59 & 0.10 & 1.52 & 0.27 & 0.09 & 4.93 & 887.7 \\
\hline & C3 & 0.17 & 443.5 & 0.88 & 0.06 & 4.10 & 0.24 & 0.28 & 8.78 & 5301 \\
\hline & $\mathrm{I} 3$ & 0.06 & 395.5 & 0.29 & $<0.01$ & 3.82 & 0.08 & 0.09 & 1.31 & 12693 \\
\hline & J3 & 0.08 & 428.5 & $<0.01$ & $<0.01$ & 3.12 & 0.13 & 0.16 & 3.93 & 5157 \\
\hline \multirow[t]{5}{*}{ "Control samples } & As & 0.15 & 31.3 & $<0.01$ & $<0.01$ & $<0.01$ & 0.03 & 0.02 & 0.04 & 110.3 \\
\hline & Bs & 0.23 & 40.0 & $<0.01$ & $<0.01$ & $<0.01$ & 0.07 & 0.04 & 4.63 & 147 \\
\hline & Cs & 0.15 & 11.0 & $<0.01$ & $<0.01$ & $\leq 0.01$ & $<0.01$ & $<0.01$ & 0.11 & 121 \\
\hline & Is & 0.13 & 9.97 & $<0.01$ & $<0.01$ & $<0.01$ & $<0.01$ & $<0.01$ & 0.07 & 146.6 \\
\hline & Js & 0.11 & 5.33 & $<0.01$ & $<0.01$ & $<0.01$ & 0.03 & $<0.01$ & 0.05 & 81.1 \\
\hline
\end{tabular}

"Without the use of complexing agents.

From Table 4, the human milk showed that the concentrations of $\mathrm{Zn}^{2+}, \mathrm{Mg}^{2+}, \mathrm{Mn}^{2+}, \mathrm{Cr}^{3+}$, $\mathrm{Cu}^{2+}, \mathrm{Fe}^{3+}$, and $\mathrm{Ca}^{2+}$ ions were, respectively, found to be in ranges of $0.07-0.56,1.03-18.65$, $<0.01-0.33,<0.01-0.86,0.06-0.17,0.10-12.26$, and $8.35-688.85 \mathrm{mg} / \mathrm{L}$ with the use of 8 hydroxyquinoline. The concentrations of $0.05-0.26,0.67-4.22,<0.01,<0.01,<0.01,<0.01-$ $0.12,0.28-7.15$, and $0.90-12.70 \mathrm{mg} / \mathrm{L}$ values for $\mathrm{Zn}^{2+}, \mathrm{Mg}^{2+}, \mathrm{Co}^{3+}, \mathrm{Cd}^{2+} \mathrm{Mn}^{2+}, \mathrm{Cr}^{3+}, \mathrm{Cu}^{2+}, \mathrm{Fe}^{3+}$, and $\mathrm{Ca}^{2+}$ ions, respectively, using APDC as complexing agent. The use of powdered activated 
carbon showed results of $\mathrm{Zn}^{2+}, \mathrm{Mg}^{2+}, \mathrm{Co}^{3+}, \mathrm{Cd}^{2+}, \mathrm{Mn}^{2+}, \mathrm{Cr}^{3+}, \mathrm{Cu}^{2+}, \mathrm{Fe}^{3+}$, and $\mathrm{Ca}^{2+}$ ions to be in the ranges of $3.51-4.61,190-258,0.74-0.88,4.60-4.37,<0.01,<0.01-0.23,0.18-0.20,12.93-$ 54.61 , and 5694-5698 $\mathrm{mg} / \mathrm{L}$, respectively.

Table 4. Concentrations of metal ions in human milk.

\begin{tabular}{|c|c|c|c|c|c|c|c|c|c|c|}
\hline $\begin{array}{l}\text { Metal ion concentration } \\
(\mathrm{mg} / \mathrm{L})\end{array}$ & & $\mathrm{Zn}$ & $\mathrm{Mg}$ & Co & $\mathrm{Cd}$ & $\mathrm{Mn}$ & $\mathrm{Cr}$ & $\mathrm{Cu}$ & $\mathrm{Fe}$ & $\mathrm{Ca}$ \\
\hline \multirow{5}{*}{$\begin{array}{l}\text { 8-Hydroxyquinoline / } \\
\text { MIBK }\end{array}$} & D1 & 0.49 & 3.01 & $<0.01$ & $<0.01$ & 0.33 & 0.08 & 0.17 & 2.36 & 78.15 \\
\hline & E1 & 0.16 & 5.28 & $<0.01$ & $<0.01$ & $<0.01$ & $<0.01$ & 0.06 & 4.26 & 233.85 \\
\hline & $\mathrm{F} 1$ & 0.56 & 18.65 & $<0.01$ & $<0.01$ & $<0.01$ & 0.04 & 0.13 & 3.96 & 668.85 \\
\hline & G1 & 0.16 & 1.03 & $<0.01$ & $<0.01$ & $<0.01$ & 0.86 & $<0.01$ & 12.26 & 24.05 \\
\hline & H1 & 0.07 & 1.17 & $<0.01$ & $<0.01$ & $<0.01$ & $<0.01$ & 0.06 & \begin{tabular}{|l|l|}
0.10 \\
\end{tabular} & 8.35 \\
\hline \multirow{3}{*}{$\begin{array}{l}\text { Ammonium pyrolidine- } \\
\text { dithiocarba-mate } \\
\text { (APDC)/MIBK }\end{array}$} & D2 & 0.07 & 4.22 & $<0.01$ & $<0.01$ & $<0.01$ & $<0.01$ & 0.09 & 0.61 & 8.00 \\
\hline & E2 & 0.05 & 0.67 & $<0.01$ & $<0.01$ & $<0.01$ & 0.12 & 0.04 & 0.28 & 0.90 \\
\hline & $\mathrm{F} 2$ & 0.26 & 3.08 & $<0.01$ & $<0.01$ & $<0.01$ & 0.04 & 0.03 & 7.15 & 12.70 \\
\hline \multirow{2}{*}{$\begin{array}{l}\text { Powdered activated } \\
\text { carbon }\end{array}$} & G3 & 4.61 & 257.5 & 0.88 & $<0.01$ & 4.60 & 0.23 & 0.18 & 54.61 & 5694 \\
\hline & $\mathrm{H} 3$ & 3.51 & 189.5 & 0.74 & $<0.01$ & 4.37 & 0.23 & 0.20 & 12.93 & 5698 \\
\hline
\end{tabular}

Analysis of variance procedure and Duncan multiple range test of variables based on type III sum of squares at $5 \%$ probability were used to ascertain statistical significant difference in variables for metal ions studied for yogurts and human milk samples. From Table 5, ANOVA data shows that $\mathrm{Zn}^{2+}, \mathrm{Mg}^{2+}$, and $\mathrm{Mn}^{2+}$ ions in yogurt exhibited the lowest significance values while $\mathrm{Cr}^{3+}$ ions has the largest value for complexing agent variability. The lower the significant values, the wider the significant difference between the complexing agent variables. Thus, there is large significant difference for $\mathrm{Zn}^{2+}, \mathrm{Mg}^{2+}$ and $\mathrm{Mn}^{2+}$ ions followed by moderate significant difference for $\mathrm{Fe}^{2+}, \mathrm{Cu}^{2+}$ and $\mathrm{Cr}^{3+}$ ions among complexing agents used. The significant difference for various samples (manufacturer) of yogurts could be ranked as:

$$
\begin{aligned}
& \mathrm{Mg}^{2+}, \mathrm{Mn}^{2+}, \mathrm{Zn}^{2+}, \mathrm{Cr}^{3+}, \mathrm{Cu}^{2+}, \mathrm{Fe}^{2+}, \mathrm{Ca}^{2+} \\
& \text { (lowest) (largest) }
\end{aligned}
$$

The significant difference for human milk as per complexing agents is ranked as:

$$
\begin{aligned}
& \mathrm{Cr}^{3+}, \mathrm{Cu}^{2+}, \mathrm{Fe}^{2+}, \quad \mathrm{Mg}^{2+}, \mathrm{Zn}^{2+}, \mathrm{Ca}^{2+} \\
& \text { (lowest) (largest) }
\end{aligned}
$$

There is a large significant difference among the complexing agents used for $\mathrm{Ca}^{2+}, \mathrm{Zn}^{2+}$ and $\mathrm{Mg}^{2+}$ ions, and little for $\mathrm{Cr}^{3+}$ ion. The significant difference for different samples of human milk is ranked as:

$$
\begin{aligned}
& \mathrm{Mg}^{2+}, \mathrm{Cu}^{2+}, \mathrm{Cr}^{3+}, \quad \mathrm{Zn}^{2+}, \quad \mathrm{Ca}^{2+}, \quad \mathrm{Fe}^{3+} \\
& \text { (lowest) (largest) }
\end{aligned}
$$


Table 5. ANOVA data for yogurts and human milk showing significant difference at 5\% probability level.

\begin{tabular}{|l|l|l|l|l|l|l|l|l|}
\hline & & $\mathrm{Zn}$ & $\mathrm{Mg}$ & $\mathrm{Mn}$ & $\mathrm{Cr}$ & $\mathrm{Cu}$ & $\mathrm{Fe}$ & $\mathrm{Ca}$ \\
\hline Yogurts & Complexing agents & 0.000 & 0.000 & 0.000 & 0.442 & 0.341 & 0.284 & 0.403 \\
\cline { 2 - 9 } & Samples/producers & 0.478 & 0.600 & 0.518 & 0.471 & 0.445 & 0.396 & 0.002 \\
\hline \multirow{2}{*}{$\begin{array}{l}\text { Human } \\
\text { milk }\end{array}$} & Complexing agents & 0.002 & 0.004 & - & 0.967 & 0.525 & 0.113 & 0.000 \\
\cline { 2 - 9 } & Samples/producers & 0.377 & 0.601 & - & 0.407 & 0.497 & 0.254 & 0.339 \\
\hline
\end{tabular}

Table 6. Duncan multiple range test data for yogurts showing significant difference at $5 \%$ probability level for complexing agents.

\begin{tabular}{|l|l|l|l|l|}
\hline Metal ions & $\mathrm{R}_{1}$ & $\mathrm{R}_{2}$ & $\mathrm{R}_{3}$ & $\mathrm{R}_{4}$ \\
\hline $\mathrm{Zn}$ & $0.224 \mathrm{c}$ & $0.032 \mathrm{a}$ & $0.176 \mathrm{bc}$ & $0.154 \mathrm{~b}$ \\
\hline $\mathrm{Mg}$ & $11.392 \mathrm{a}$ & $3.168 \mathrm{a}$ & $416.000 \mathrm{~b}$ & $19.526 \mathrm{a}$ \\
\hline $\mathrm{Mn}$ & $0.104 \mathrm{a}$ & $0.036 \mathrm{a}$ & $3.364 \mathrm{~b}$ & $0.000 \mathrm{a}$ \\
\hline $\mathrm{Cr}$ & $0.150 \mathrm{a}$ & $0.710 \mathrm{a}$ & $0.340 \mathrm{a}$ & $0.026 \mathrm{a}$ \\
\hline $\mathrm{Cu}$ & $0.100 \mathrm{a}$ & $0.226 \mathrm{a}$ & $0.184 \mathrm{a}$ & $0.012 \mathrm{a}$ \\
\hline $\mathrm{Fe}$ & $1.654 \mathrm{a}$ & $4.464 \mathrm{a}$ & $5.672 \mathrm{a}$ & $0.980 \mathrm{a}$ \\
\hline $\mathrm{Ca}$ & $27.760 \mathrm{a}$ & $67.794 \mathrm{a}$ & $5888.868 \mathrm{~b}$ & $121.088 \mathrm{a}$ \\
\hline
\end{tabular}

$\mathrm{R}_{1}$ : 8-hydroxyquinoline; $\mathrm{R}_{2}$ : ammonium pyrrolidinedithiocarbamate; $\mathrm{R}_{3}$ : activated carbon; $\mathrm{R}_{4}$ : control (without any complexing agent). Values carrying the same letters are not significantly different while those with different letters are significantly different as per complexing agent variables.

Table 7. Duncan multiple range test data for human breast milk showing significant difference at $5 \%$ probability level for complexing agents.

\begin{tabular}{|l|l|l|l|}
\hline Metal ions & $\mathrm{R}_{1}$ & $\mathrm{R}_{2}$ & $\mathrm{R}_{3}$ \\
\hline $\mathrm{Zn}$ & $0.338 \mathrm{a}$ & $0.137 \mathrm{a}$ & $4.130 \mathrm{~b}$ \\
\hline $\mathrm{Mg}$ & $6.072 \mathrm{a}$ & $2.977 \mathrm{a}$ & $224.085 \mathrm{~b}$ \\
\hline $\mathrm{Cr}$ & $0.206 \mathrm{a}$ & $0.087 \mathrm{a}$ & $0.390 \mathrm{a}$ \\
\hline $\mathrm{Cu}$ & $1.478 \mathrm{a}$ & $0.073 \mathrm{a}$ & $0.210 \mathrm{a}$ \\
\hline $\mathrm{Fe}$ & $4.712 \mathrm{a}$ & $2.700 \mathrm{a}$ & $34.250 \mathrm{~b}$ \\
\hline $\mathrm{Ca}$ & $203.840 \mathrm{a}$ & $7.700 \mathrm{a}$ & $5713.050 \mathrm{~b}$ \\
\hline
\end{tabular}

$\mathrm{R}_{1}$ : 8-hydroxyquinoline; $\mathrm{R}_{2}$ : ammonium pyrrolidinedithiocarbamate; $\mathrm{R}_{3}$ : activated carbon. Values carrying the same letters are not significantly different while those with different letters are significantly different as per complexing agent variables.

A large significant difference exists among the human milk samples for $\mathrm{Zn}^{2+}$ while it is small for $\mathrm{Mg}^{2+}$ ion. The significant difference among the human milk for others falls within the range. This may indicate that the diet consumed by the lactating mothers that could have supplied these metal ions into their human milk is more or less not the same in concentration in the third world countries like Nigeria. Tables 6 and 7 show the significant difference of complexing agents in Yogurts and human milk, respectively, for determined metal ions while Table 8 indicates the significant difference of variables of human milk samples with the metal ions. There is no significant difference among the complexing agents studied for preconcentration of $\mathrm{Cr}^{3+}, \mathrm{Cu}^{2+}$ and $\mathrm{Fe}^{3+}$ metal ions in yogurts. There is also no significant difference among the complexing agents studied for pre-concentration of $\mathrm{Cr}^{3+}$ and $\mathrm{Cu}^{2+}$ ions in human milk samples. However, there is significant difference among the three complexing agents studied for pre-concentration of $\mathrm{Zn}^{2+}$ ion in yogurts. There is no significant difference between APDC/MIBK and 8-hydroxyquiniline/MIBK complexing agents for $\mathrm{Mg}^{2+}, \mathrm{Mn}^{2+}, \mathrm{Cr}^{3+}, \mathrm{Cu}^{2+}, \mathrm{Fe}^{3+}$ and $\mathrm{Ca}^{2+}$ ions while there is significant difference between activated carbon/ $/ \mathrm{HNO}_{3}$ complexing agents and the other two complexing agents for $\mathrm{Zn}^{2+}, \mathrm{Mg}^{2+}, \mathrm{Mn}^{2+}$ and $\mathrm{Ca}^{2+}$ ion in yogurts. There 
is also significant difference between activated carbon/ $\mathrm{HNO}_{3}$ complexing agent and the other two complexing agents studied for $\mathrm{Zn}^{2+}, \mathrm{Mg}^{2+}, \mathrm{Fe}^{3+}$ and $\mathrm{Ca}^{2+}$ ions in human milk samples. Furthermore, the presence of $\mathrm{Co}^{3+}$ and $\mathrm{Cd}^{2+}$ ions were lower than $0.01 \mathrm{mg} / \mathrm{L}$ with either 8hydroxyquinoline or APDC complexing agents. However, $\mathrm{Co}^{3+}$ ion was detected with the use of activated carbon. There was no $\mathrm{Cd}^{2+}$ ion found in any of the human milk samples. The ranking of the complexing ability of the three-complexing agents considered for human milk was found to follow almost the same trend as those of the yogurt samples. Thus:

for $\mathrm{Zn}^{2+}$ : activated carbon- $\mathrm{HNO}_{3}>$ 8-hydroxylquinoline-MIBK > APDC-MIBK;

for $\mathrm{Mg}^{2+}$ and $\mathrm{Ca}^{2+}$ : activated carbon $\mathrm{HNO}_{3}>$ 8-hydroxylquinoline-MIBK >APDC-MIBK;

for $\mathrm{Mn}^{2+}$ : activated carbon- $\mathrm{HNO}_{3}>8$-hydroxylquinoline-MIBK > APDC-MIBK;

for $\mathrm{Cr}^{3+}$ : activated carbon- $\mathrm{HNO}_{3}>$ APDC-MIBK > 8-hydroxylquinoline-MIBK;

for $\mathrm{Cu}^{2+}$ : activated carbon- $\mathrm{HNO}_{3}>8$-hydroxylquinoline-MIBK > APDC-MIBK;

for $\mathrm{Fe}^{3+}$ : activated carbon- $\mathrm{HNO}_{3}>8$-hydroxylquinoline-MIBK $>$ APDC-MIBK.

Table 8. Duncan multiple range test data for human milk showing significant difference at $5 \%$ probability level for samples.

\begin{tabular}{|l|l|l|l|l|l|l|}
\hline Samples & $\mathrm{Zn}$ & $\mathrm{Mg}$ & $\mathrm{Cr}$ & $\mathrm{Cu}$ & $\mathrm{Fe}$ & $\mathrm{Ca}$ \\
\hline $\mathrm{D}$ & $0.310 \mathrm{a}$ & $3.900 \mathrm{a}$ & $0.055 \mathrm{a}$ & $0.145 \mathrm{a}$ & $1.515 \mathrm{a}$ & $43.900 \mathrm{a}$ \\
\hline $\mathrm{E}$ & $0.135 \mathrm{a}$ & $3.260 \mathrm{a}$ & $0.085 \mathrm{a}$ & $3.530 \mathrm{a}$ & $2.305 \mathrm{a}$ & $118.200 \mathrm{a}$ \\
\hline $\mathrm{F}$ & $0.414 \mathrm{a}$ & $11.135 \mathrm{a}$ & $0.065 \mathrm{a}$ & $0.095 \mathrm{a}$ & $5.580 \mathrm{ab}$ & $341.700 \mathrm{a}$ \\
\hline $\mathrm{G}$ & $2.430 \mathrm{~b}$ & $129.730 \mathrm{~b}$ & $0.630 \mathrm{a}$ & $0.100 \mathrm{a}$ & $33.705 \mathrm{~b}$ & $2868.250 \mathrm{~b}$ \\
\hline $\mathrm{H}$ & $1.865 \mathrm{~b}$ & $95.705 \mathrm{~b}$ & $0.200 \mathrm{a}$ & $0.145 \mathrm{a}$ & $6.975 \mathrm{ab}$ & $2862.150 \mathrm{~b}$ \\
\hline
\end{tabular}

Values carrying the same letters are not significantly different while those with different letters are significantly different as per different sources of human breast milk sample variables.

In the naturally synthesized milk as in the case of human milk, activated carbon exhibited the highest complexing ability for all the metal ions when compared with those of 8 hydroxyquinoline and APDC. The effect of pre-concentration ability of activated carbon/ $\mathrm{HNO}_{3}$ is evidenced for $\mathrm{Mn}^{2+}$ ion whereby the other two complexing agents could not complex the $\mathrm{Mn}^{2+}$ ion in the human milk filtrate. Cadmium was lower than $0.01 \mathrm{mg} / \mathrm{L}$ in human milk but activated carbon powder- $\mathrm{HNO}_{3}$ acid revealed its presence in some of the yogurt samples. The concentration of $\mathrm{Zn}^{2+}$ ions of $3.51-4.61 \mathrm{mg} / \mathrm{L}$ in human milk of some Nigerian women in the study is lower than the maximum acceptable value of WHO $(5.0 \mathrm{mg} / \mathrm{L})$ and U.S. Public Health Service of $5.0 \mathrm{mg} / \mathrm{L}$ standards for drinking water. The concentration of $\mathrm{Mn}^{2+}$ ion of $4.60-4.37$ $\mathrm{mg} / \mathrm{L}$ in this study is higher than that of WHO value of $0.5 \mathrm{mg} / \mathrm{L}$ which is the allowable maximum concentration while values of $0.23 \mathrm{mg} / \mathrm{L}$ for $\mathrm{Cr}^{3+}$ is also higher than $0.05 \mathrm{mg} / \mathrm{L}$ maximum allowable of U.S. Public Health Service standards for drinking water. The concentration of $\mathrm{Cu}^{2+}$ ion of $0.18-0.20 \mathrm{mg} / \mathrm{L}$ is lower than the WHO maximum acceptable value of $1.0 \mathrm{mg} / \mathrm{L}$ for drinking water while the range of $12.93-54.61 \mathrm{mg} / \mathrm{L}$ for $\mathrm{Fe}^{2+}$ is far higher than that of the WHO allowable maximum for drinking water [17]. The concentration of $\mathrm{Cd}^{2+}$ in the range of $0.06-0.10 \mathrm{mg} / \mathrm{L}$ in two samples of yogurts studied is comparable to $0.1 \mathrm{mg} / \mathrm{L}$ of the U.S. Public Health Service quality standards for drinking water. Cadmium being a toxic metal ion is present in lower concentration below the detection limit of FAAS, that is, $<0.001$. Furthermore, the result of calcium content of human lactating mothers milk samples as shown in Table 4 was found to be in the range of $569.4-569.8 \mathrm{mg} / 100 \mathrm{~mL}$. This value is also higher than the WHO threshold value of $30 \mathrm{mg} / 100 \mathrm{~mL}$. The value obtained in this study is higher than $17.6-25.0 \mathrm{mg} / 100 \mathrm{~mL}$ value of previous work reported in literature [12]. Some factors that may be responsible for these differences include nutritional status, age of lactating mothers and health status of mother during pregnancy period. Analytical method used in this study is also 
suggested to be a major factor in that the human milk samples were deproteinized before preconcentration with complexing agent which were not used in the one reported in literature [16]. The magnesium content of the human milk was also determined to be in the range of 18.95$25.75 \mathrm{mg} / 100 \mathrm{~mL}$ and is higher than the WHO value of $7.0 \mathrm{mg} / 100 \mathrm{~mL}$ [12]. The above factors enumerated for calcium content could also be applied for the difference in magnesium content concentration.

\section{CONCLUSION}

In conclusion, the use of powdered activated carbon, as a pre-concentration agent may remain indispensable in concentration determination and in separation techniques of different metal ions in human milk and yogurt samples.

\section{REFERENCES}

1. Tver, D.F.; Russell. P. The Nutrition and Health Encyclopedia, Litton Educational Publishing, Inc.: New York; 1981; pp 79-81.

2. Walshe, J.M. J. Resident College Physicians, London 1995, 29, 280.

3. Bosco, P.; Di-Gioacchino, M; Conti, P.; Barbacane, R.C.; Andreassi, M.; Di-Giacomo, F.; Sabbioni, E. Life Sci. 1998, 63, 1417.

4. Shapcott, D.; Khoury, K.; Demers, P.P.; Vobecky, J. Clin. Biochem. 1977, 10, 178.

5. Kucera, J.; Benckov, V.; Sabbioni, E; van-dervenne, M.T. Sci. Total. Environ. 1995, 166, 221.

6. Rajalakshmi, K.; Srikantia, S.E. Am. J. clin. Nutr. 1980, 33, 664.

7. Moser-Veillon, P.M. Analyst 1995, 120, 895.

8. Lu, H; Zhang, X.H. Chung.Hua.Hu.Li.Tsa.Chich 1995, 30, 519.

9. Zavaleta, N.; Lanata, C.; Butron, B.; Person, J.M.; Brown, K.H.; Lonnerdal, B. Am. J. Clin. Nutr. 1995, 62, 559.

10. Gibson, R.S.; Ferguson, E.L.; Lehfeid, J. Euro. J. Clin. Nutr. 1999, 52, 764.

11. Miller, S.A.; Chopra, J.G. American Academy of Pediatrics 1984, 74, 639.

12. Jimenez, Dolores Alvarez M.; Gil, M. Isabel Serrano Gil; Palacio-Corvillo, M. Antonia; Polo Diez, Luis M. Analyst 1988, 113, 635.

13. Subramanian, K.S.; Meranger, J.C. Intern. J. Environ. Anal. Chem. 1979, 7, 25.

14. Kinrade, J.D.; Van-Loon, J.C.V. Anal. Chem. 1974, 46, 1894.

15. Allen, E.A.; Bartelett, P.K.N.; Ingram, G. Analyst 1984, 109, 1075.

16. Egila, J.N.; Mbidomti, H.J. J. Chem. Soc. Nigeria 1996, $21,92$.

17. Macrae, R.; Robinson, R.K.; Sadler, M.J. Encyclopedia of Food Science, Food Technology and Nutrition, Vol. 2, Academic Press: London; 1993; pp 972-979. 